\title{
ORAL HYGIENE HABITS AMONG THE STUDENTS OF THE UNIVERSITY OF NIŠ IN SOUTHERN SERBIA - A PILOT STUDY
}

\author{
Marija Bojović1,2, Milica Petrović2, Radmila Obradović1,2, \\ Saša Bubanj ${ }^{3}$, Rade Jovanović ${ }^{4}$, Ljiljana Kesić1,2
}

\begin{abstract}
Oral hygiene is one of the most important factors which affects the status of general health in all patients. These factors may affect the individual's oral hygiene habits: age, gender, education, level of awareness and socioeconomic status. Oral hygiene habits among the students who live in southern Serbia have been rarely investigated. The aim of this study was to investigate oral hygiene habits among the students of the University of Niš, southern Serbia.

The study involved 249 students (53.83\% male and $46.17 \%$ female), and each participant completed the study questionnaire.

Average age of the participants was $21.67 \pm 2.00$ years. The prevalence expressed in percentages was as follows: $100 \%$ used toothbrush and toothpaste for oral hygiene, $77.51 \%$ used dental flossing, $40.96 \%$ used mouthrinse solutions, $63.45 \%$ brushed their teeth twice per day, $69.88 \%$ used combined toothbrush movements, $20.88 \%$ used vertical toothbrush movements, $9.24 \%$ used horizontal toothbrush movements and $54.62 \%$ changed their toothbrushes every 3 months. A significantly high percent $(92.37 \%)$ of students used chewing gum and $59.84 \%$ consumed sweets every day, but a significantly low percent of students were active smokers (17.67\%), former smokers $(11.24 \%)$ and drugs users $(13.65 \%)$. The percentage of nail biters among the students was $41.31 \%$.

The study may highlight the interactions between oral hygiene and related habits. Further research is needed to develop good oral hygiene skills for achieving and maintaining good oral and dental health.
\end{abstract}

Acta Medica Medianae 2017;56(4):114-119.

Key words: oral hygiene habits, oral health, students

${ }^{1}$ University of Niš, Faculty of Medicine, Niš, Serbia ${ }^{2}$ Dental Clinic, Department of Oral Medicine and Periodontology, Niš, Serbia

${ }^{3}$ Faculty of Sport and Physical Education, Niš, Serbia

${ }^{4}$ Faculty of Sport and Physical Education, DDS student, Niš, Serbia

Contact: Ljiljana Kesić

Bulevar dr Zorana Đinđića 81, 18000 Niš, Serbia

E mail kesic.ljiljana@gmail.com

\section{Introduction}

Oral hygiene is one of the most important factors which affect the general health. Consequently, it is important to estimate the factors of influence on oral hygiene habits and to improve preventive strategies. Hygiene behavior models have usually been considered as a part of general health behavior models (1). Health behavior, as defined by Steptoe et al. (1994) (2), involves "the activities undertaken by people in order to protect, promote or maintain health, and to prevent disease".

The factors that may have influence on individual and community health behavior are knowledge, beliefs, values, attitudes, skills, finance, materials, time and influence of family members, friends, co-workers, opinion leaders and even health workers themselves (3). Therefore, studies have used health behavior models to explain the indicators and development of hygiene behavior models (4-6). Unsurprisingly, since hygiene beha-vior models are very different from other health behavior models such as dietary behavior models, current health behavior models fail to explain and predict hygiene behavior models $(7,8)$. Personal oral hygiene is often considered as an essential factor in the control of chronic periodontal disease (9).

Maintaining good oral hygiene can prevent periodontal disease and tooth decay, which may contribute to different serious conditions, including heart disease, diabetes, respiratory diseases, and premature and low weight babies. Poor oral hygiene can also affect the ability to chew and digest food properly, that can result in digestive disorders and bad breath (halitosis). 
It is considered that a proper toothbrush technique is the main prerequisite for maintaining good oral hygiene, and additional tools in that regard are toothpaste, dental floss, interdental stimulator, toothpicks, mouthrinse solutions etc.

Personal factors may affect an individual's oral hygiene practices, such as age, gender, education, level of awareness and socioeconomic status. It has been accepted that there is an association between higher socioeconomic status and lower risk of unhealthy oral health related behavior models (10).

Certain groups of people are more receptive to information and instruction of oral hygiene habits than others. Students with a developing awareness of themselves and interests in their general appearance and wellbeing are expected to be very receptive and that they possess excellent oral hygiene practices. Healthy lifestyle habits are fundamental to public health (11).

Oral hygiene habits among the students living in southern Serbia have not been sufficiently investigated. The knowledge about oral hygiene behavior models could improve preventive procedures.

\section{Aim}

The aim of the current study was to estimate oral hygiene habits among the students of University of Niš, southern Serbia.

\section{Material and methodology}

The study involved 249 students, and each participant completed the study questionnaire. The examination was performed by the same investigator (Appendix). The questionnaire had been structured to obtain the information about age, gender, oral hygiene habits (using additional instruments for oral hygiene, toothbrush movements, toothbrush replacement frequency, consumption of sweets, using of chewing gum, bad habits like nail biting, cigarette smoking or drug abuse among the students). The study was approved by the institutional Ethics Committee Faculty of Medicine, University of Niš (No. 01-3565-3). The procedures had been designed to protect the students' privacy and to allow anonymous participation.

Continuous (measurable) data were expressesed as mean value \pm standard deviation (mean $\pm \mathrm{sd}$ ). Discontinuous (attribute) data were presented as frequencies and percentages.

\section{Results}

The study involved 249 students (53.83\% male and $46.17 \%$ female). The average age of the participants was $21.67 \pm 2.00$ years and all of them used toothbrush and toothpaste for oral hygiene.

The percentage of students who used additional instruments for oral hygiene (dental floss) was $77.51 \%$, and that was a significantly higher per- centage of participants $(p<0.001)$. A significantly lower number of participants, $102(40.96 \%)$, used mouthrinse solutions $(p<0.01)$ (Table 1$)$.

Table 1. Usage of additional instruments for oral hygiene

\begin{tabular}{||c|c|c||}
\hline \hline $\begin{array}{c}\text { Use additional instruments for } \\
\text { Oral hygiene (dental floss) }\end{array}$ & 193 & $(77.51 \%)$ \\
\hline Used mouthrinse solution & 102 & $(40.96 \%)$ \\
\hline
\end{tabular}

Most of the participants brushed their teeth twice per day $(63.45 \%)$; that was a significantly higher percentage than that of participants who brushed their teeth once or three times per day ( $p$ $<0.001$ ) (Table 2).

Table 2. Movements for brushing teeth

\begin{tabular}{|c|c|c|}
\hline Brushe their teeth per day & & \\
\hline 1 & 17 & $(6.83 \%)$ \\
\hline 2 & 158 & $(63.45 \%)$ \\
\hline 3 & 74 & $(29.72 \%)$ \\
\hline Total & 249 & $(100.00 \%)$ \\
\hline
\end{tabular}

There was a significantly higher number of participants $(174$, i.e. $69.88 \%$ ) who used combined toothbrush movements, than those who used only vertical (52, i.e. $20.88 \%)$ and only horizontal (23, i.e. $9.24 \%$ ) toothbrush movements ( $p<$ 0.001) (Table 3).

Table 3. Distribution of tootbrush movements in participants

\begin{tabular}{||c|c|c||}
\hline Toothbrush movements & & \\
\hline \hline Vertical & 52 & $20.88 \%$ \\
\hline Horizontal & 23 & $9.24 \%$ \\
\hline Combined & 174 & $69.88 \%$ \\
\hline Total & 249 & $100.00 \%$ \\
\hline
\end{tabular}

Most of the participants (136, i.e. $54.62 \%$ ) replaced their toothbrushes every 3 months and that number was significantly higher than the number of those who replaced toothbrushes every 6 months, 1 year or longer $(p<0.001)$ (Table 4).

Table 4. The percentage of replacement toothbrush period in participants

\begin{tabular}{||c|c|c||}
\hline Replacement toothbrush period & & \\
\hline \hline Every 3 months & 136 & $54.62 \%$ \\
\hline 6 meseci & 99 & $39.76 \%$ \\
\hline 1 godina & 12 & $4.82 \%$ \\
\hline Duže & 2 & $0.80 \%$ \\
\hline Total & 249 & $100.00 \%$ \\
\hline
\end{tabular}

The percentage of participants who consumed sweets every day was $59.84 \%$ and that was a significantly higher percentage than that for occasional consumption and avoidance of sweets altogether $(p<0.001)$ (Table 5). 
Table 5. The percentage of sweets consumption in participants

\begin{tabular}{|c|c|c|}
\hline Sweets consumation & & \\
\hline \hline Everyday consumation & 149 & $(59.84 \%)$ \\
\hline Occasional consumption & 93 & $(37.35 \%)$ \\
\hline Avoiding of sweets & 7 & $(2.81 \%)$ \\
\hline Total & 249 & $(100.00 \%)$ \\
\hline
\end{tabular}

There was a low number of active and former smokers and those who used drugs ( $p<$ $0.001)$, and the percentage of nail biters among the students was $41.31 \% \quad(p<0.01)$. A significantly high number of participants used chewing gum (230, i.e. $92.37 \%)(p<0.001)$ (Table 6).

Table 6. The percentage of habits in the participants

\begin{tabular}{|c|c|c|}
\hline Active smoker & 44 & $(17.67 \%)$ \\
\hline Former smoker & 28 & $(11.24 \%)$ \\
\hline Drugs users & 34 & $(13.65 \%)$ \\
\hline Nail biters & 103 & $(41.37 \%)$ \\
\hline Chewing gum users & 230 & $(92.37 \%)$ \\
\hline
\end{tabular}

\section{Discussion}

Previous studies (12-17) showed that health behavior models of students are associated with factors such as gender, age, oral health knowledge and attitudes, parental income and educational background, ethnic group and environment. In developed and even more in developing countries, physical activity, tobacco and alcohol use, general hygiene habits and diets are the major risk factors for chronic disease (18) and may also be linked to oral health (19-21). The American Dental Association advised that teeth should be brushed at least twice a day (22) and dental floss should be used at least once a day (23).

In the present study, the percentage of participants who brushed their teeth twice per day was $63.45 \%$, while in a study (24) among Italian students, $92 \%$ of them brushed their teeth at least twice per day. In Sweden, around $85 \%$ of 20-25-years-old Swedes brushed their teeth once or twice per day (25). In Kuwait, 34\% of health sciences college students brushed their teeth twice or more per day (26). The percentage of Turkish students who brushed their teeth twice or more per day was $67.6 \%$ (27). According to a study by Khami, $93 \%$ of Iranian dental students brushed their teeth at least once per day and $57 \%$ at least twice per day (28). In a study (29) among Iranian students, $69.9 \%$ of them brushed their teeth once or twice per day, $28.6 \%$ brushed their teeth three or more times per day and $1.5 \%$ never brushed their teeth. In India, among dental students in Namakkal (30), $66 \%$ of examinees brushed their teeth twice per day.

In our study, $77.51 \%$ of students used dental floss. In other studies the rate of dental flossing was $14.9 \%$ in Italy (24), $7 \%$ in Sweden (25), $28 \%$ in the United Kingdom (31) and 3\% in Turkey (27), which was a significantly lower percen116 tage than in our examination. Kawamura showed that the use of dental floss is not common among Japanese students (32). According to a study by Khami, $52 \%$ of Iranian dental students used dental floss at least once per day (28). It is established that toothbrushing was not enough for the removal of dental plaque and daily use of dental floss was thus suggested (33).

The percentage of students who used mouthrinse solutions was $40.96 \%$, and that was a higher percentage than in an Iranian study (29), where $21.4 \%$ of students used mouthwashes and in an Italian study where only $12.8 \%$ of students used mouthwash solutions (24).

In this study, the majority of participants, $54.62 \%$, replaced their toothbrushes every 3 months, and that was the recommendation by toothbrush manufacturers or by their dentist. In the study by Kirtiloglu (27), $49 \%$ of subjects and in the study by Rimondini (24) $81.6 \%$ of subjects replaced their toothbrushes every 3 months. About $33.9 \%$ of Iranian students (29) replaced their toothbrushes every 3 months.

Smoking affects the whole oral and systemic health (34). In the present study, the rate of smokers was $17.67 \%$. In accordance with this, in our study, the rate was lower than both general university students rate $(42.5 \%-49.4 \%)$ and population smoking rate $(33.4 \%)(35,36)$.

Incorporating oral health promotion into general health promotion is becoming increasingly important, and as an integrated approach it is likely to be more cost-effective than the programs targeting single diseases (37). According to the study by Mizutani et al. (38) indicating that higher self-efficacy in university students correlates with better oral health behaviors and gingival health, enhancing self-efficacy may be a useful approach to prevent gingivitis in university students.

\section{Conclusion}

The study of oral hygiene habits serves the public oral health needs. Implementation of successful oral hygiene promotion programs depends on the prevalence of such oral hygiene behavior models, as well as on understanding of their determinants. The study may highlight the interactions between oral hygiene related habits. The information about the patterns of oral hygiene related habits can provide important data for the adjustment of oral health education in the context of oral health promotion programs. Further research is needed to improve good oral hygiene skills in achieving and maintaining good oral health.

\section{Acknowledgment}

This work was financially supported partly by the Ministry of Education, Science and Technological Development of the Republic of Serbia, grants No. III 46013 and No. III 41018 .

\section{Conflict of interest} interest.
The authors declare that they have no conflict of 


\section{References}

1. Dorri M, Sheiham A, Watt RG. Modelling the factors influencing general and oral hygiene behaviours in adolescents. Internat J Paediatr Dent. 2010; 20(4): 261-9. [CrossRef][PubMed]

2. Steptoe A, Wardle J, Vinck J, Tuomisto M, Holte A, Wichstrøm L. Personality and attitudinal correlates of healthy and unhealthy lifestyles in young adults. Psychol Health. 1994; 9(5): 331-3. [CrossRef] [PubMed]

3. Park K. Park's Textbook of Preventive and Social Medicine, $18^{\text {th }}$ ed. Banarsidas Bhanot Publishers; 2005.

4. Tillis TS, Stach DJ, Cross-Poline GN, Annan SD, Astroth DB, Wolfe P. The transtheoretical model applied to an oral self-care behavioral change: development and testing of instruments for stages of change and decisional balance. J Dent Hyg. 2003; 77(1): 16-25. [PubMed]

5. Ayo-Yusuf OA, Reddy PS, van den Borne BW. Adolescents' sense of coherence and smoking as longitudinal predictors of self-reported gingivitis. J Clin Periodontol. 2008; 35(11): 931-7. [CrossRef] [PubMed]

6. Morowatisharifabad M, Shirazi KK. Determinants of oral health behaviors among preuniversity [12thgrade] students in Yazd [Iran]: an application of the health promotion model. Fam Community Health. 2007; 30(4): 342-50. [CrossRef][PubMed]

7. Arheiam A, Bankia, I, Ingafou $M$. Perceived competency towards preventive dentistry among dental graduates: the need for curriculum change. Libyan J Med. 2015; 10:26666. [PubMed]

8. Ndiokwelu E. Applicability of Rosenstock-Hochbaum health behaviour model to prevention of periodontal disease in Enugu students. Odontostomatol Trop. 2004; 27(106): 4-8. [PubMed]

9. Loe H. Periodontal disease as we approach the year 2000. J Periodontol. 1994: 65(5): 464-7. [CrossRef] [PubMed]

10. Bernabe E, Watt RG, Sheiham A, Suominen-Taipale $A L$, Nordblad A, Savolainen J, et al. The influence of sense of coherence on the relationship between childhood socio-economic status and adult oral health-related behaviours. Community Dent Oral Epidemiol. 2009; 37(4): 357-65. [CrossRef] [PubMed]

11. Kolawole K, Oziegbe E, Bamise C. Oral hygiene measures and the periodontal status of school children. Int J Dent Hyg. 2011; 9(2): 143-8. [CrossRef] [PubMed]

12. Ostberg AL, Halling A, Lindblad $U$. A gender perspective of self-perceived oral health in adolescents: associations with attitudes and behaviours. Community Dent Health. 2001; 18(2): 110-6. [CrossRef][PubMed]

13. Ostberg $A L$, Jarkman $K$, Lindblad $U$, Halling $A$. Adolescents' perceptions of oral health and influencing factors: a qualitative study. Acta Odontol Scand. 2002; 60(3): 167-73. [CrossRef] [PubMed]

14. Kuusela S, Kannas L, Tynjala J, Honkala E, Tudor Smith C. Frequent use of sugar products by schoolchildren in 20 European countries, Israel and
Canada in 1993/1994. J Dent Res. 1997; 76(9): 1602-9. [CrossRef][PubMed]

15. Nicolau B, Marcenes W, Bartley M, Sheiham A. Associations between socio-economic circumstances at two stages of life and adolescents' oral health status. J Public Health Dent. 2005; 65(1): 14-20. [CrossRef][PubMed]

16. Sundby A, Petersen PE. Oral health status in relation to ethnicity in the Municipality of Copenhagen, Denmark. Int J Paediatr Dent. 2003; 13(3): 150-7. [CrossRef][PubMed]

17. World Health Organization. The health of youth: health behaviour in school-aged children. Copenhagen: World Health Organization Regional Office for Europe; 1996.

18. World Health Organization. The World Health Report 2002. Reducing risks, promoting healthy life. Geneva: World Health Organization; 2002.

19. Reibel J. Tobacco and oral diseases: an update of the evidence, with recommendations. Med Principles Pract. 2003; 12(1): 22-32. [CrossRef] [PubMed]

20. Tezal M, Grossi SG, Ho AW, Genco RJ. Alcohol consumption and periodontal disease. The Third National Health and Nutrition Examination Survey. J Clin Periodontol. 2004; 31(7): 484-8. [CrossRef] [PubMed]

21. Moynihan P, Petersen PE. Diet, nutrition and the prevention of dental diseases. Public Health Nutr. 2004; 7(1A): 201-26. [CrossRef][PubMed]

22. American Dental Association. Basic brushing. Chicago: American Dental Association, Division of Communications; 1996.

23. American Dental Association. Basic flossing. Chicago: American Dental Association, Division of Communications; 1984.

24. Rimondini L, Zolfanelli B, Bernardi F, Bez C. Selfpreventive oral behavior in an Italian university student population. J Clin Periodontol. 2001; 28(3): 207-11. [CrossRef][PubMed]

25. Stenberg P, Hakansson J, Akerman S. Attitudes to dental health and care among 20 to 25-year-old Swedes: Results from a questionnaire. Acta Odontol Scand. 2000; 58(3): 102-6. [CrossRef][PubMed]

26. Al-Ansari J, Honkala E, Honkala S. Oral health knowledge and behavior among male health sciences college students in Kuwait. BMC Oral Health. 2003; 3: 2. [CrossRef][PubMed]

27. Kirtiloglu T, Yavuz US. An assessment of oral selfcare in the student population of a Turkish university. Public Health. 2006; 120(10): 953-7. [CrossRef][PubMed]

28. Khami MR, Virtanen JI, Jafarian M, Murtomaa $H$. Oral health behaviour and its determinants amongst Iranian dental students. Eur J Dent Educ. 2007; 11(1): 42-7. [CrossRef][PubMed]

29. Neamatollahi $H$, Ebrahimi $M$. Oral health behavior and its determinants in a group of Iranian students. Indian J Dent Res. 2010; 21(1): 84-8. [CrossRef] [PubMed]

30. Elavarasu S, Thangavelu A, Sekar S, Saravanan J, Selvaraj S. Evaluation of oral hygiene practices and awareness among dental students in Namakkal district. Int J of Clin Dent Sci. 2014; 5 (2). 
31. Nuttall NM, Bradnock G, White D, Morris J, Nunn J. Dental attendance in 1998 and implications for the future. Br Dent J. 2001; 190(4): 177-82. [CrossRef] [PubMed]

32. Kawamura M, Ikeda-Nakaoka Y, Sasahara H. An assessment of oral self-care level among Japanese dental hygiene students and general nursing students using the Hiroshima University-Dental Behavioural Inventory [HU-DBI]: Surveys in 1990/1999. Eur J Dent Educ. 2000; 4(2): 82-8. [CrossRef][PubMed]

33. Newman MG, Takei HH, Klokkevold PR, Carranza FA. Carranza's clinical periodontology. In: Perry DA. Plaque control for the periodontal patient. $10^{\text {th }}$ ed. Philadelphia: Elsevier Saunders; 2006. p. 728-48.

34. Millar WJ, Locker D. Smoking and oral health status. J Can Dent Assoc. 2007; 73(2): 155. [PubMed]
35. Erdogan N, Erdogan I. Smoking at school: views of Turkish university students. Int J Environ Res Public Health. 2009; 6(1): 36-50. [CrossRef][PubMed]

36. Oksuz E, Mutlu ET, Malhan S. Characteristics of daily and occasional smoking among youths. Public Health. 2007; 121(5): 349-56. [CrossRef][PubMed]

37. Petersen PE. The World Oral Health Report 2003: continuous improvement of oral health in the $21^{\text {st }}$ century-the approach of WHO Global Oral Health Programme. Community Dent Oral Epidemiol. 2003; 31(1): 3-24. [CrossRef][PubMed]

38. Mizutani S, Ekuni D, Furuta M, Tomofuji T, Irie K, Azuma $T$, et al. Effects of self-efficacy on oral health behaviours and gingival health in university students aged 18- or 19-years-old. J Clin Periodontol. 2012; 39(9): 844- 9. [CrossRef] [PubMed] 


\title{
NAVIKE U ODRŽAVANJU ORALNE HIGIJENE KOD STUDENATA UNIVERZITETA U NIŠU U JUŽNOJ SRBIJI: PILOT STUDIJA
}

\author{
Marija Bojović1,2, Milica Petrović ${ }^{2}$, Radmila Obradović1,2, \\ Saša Bubanj ${ }^{3}$, Rade Jovanović4 ${ }^{4}$ Ljiljana Kesić1,2
}

\author{
${ }^{1}$ Univerzitet u Nišu, Medicinski fakultet, Niš, Srbija \\ ${ }^{2}$ Klinika za stomatologiju, Odeljenje parodontologije i oralne medicine, Niš, Srbija \\ ${ }^{3}$ Fakultet sporta i fizičkog vaspitanja, Niš, Srbija \\ ${ }^{4}$ Fakultet sporta i fizičkog vaspitanja, Niš, DDS student, Srbija \\ Kontakt: Ljiljana Kesić \\ Bul. dr Zorana Đinđića 81, 18000 Niš, Srbija \\ E-mail: kesic.ljiljana@gmail.com
}

Oralna higijena je jedan od najvažnijih faktora koji utiče na opšte zdravstveno stanje kod pacijenata. Sledeći faktori mogu uticati na navike u održavanju oralne higijene pojedinca: starost, pol, obrazovanje, nivo svesti i socioekonomski status. Oralno-higijenske navike među studentima koji žive na jugu Srbije retko su istraživani.

Cilj ove studije bio je istražiti oralno-higijenske navike među studentima Univerziteta u Nišu na jugu Srbije.

U studiju je uključeno 249 studenata (53,83\% muškaraca i 46,17\% žena), a svaki učesnik je popunio upitnik.

Prosečna starost učesnika bila je $21,67 \pm 2,00$ godina. Prevalencija izražena u procentima bila je sledeća: $100 \%$ učesnika koristi četkicu za zube i zubnu pastu za oralnu higijenu; $77,51 \%$ koristi zubni konac; $40,96 \%$ koristi vodicu za ispiranje usta; $63,45 \%$ pere zube dva puta dnevno; 69,88\% koristi kombinovane pokrete pranja zuba; $20,88 \%$ koristi vertikalne pokrete prilikom pranja zuba, dok 9,24\% koristi horizontalne pokrete prilikom pranja zuba. Četkicu za zube menja $54,62 \%$ učesnika na svaka tri meseca. Značajno visok procenat $(92,37 \%)$ učenika koristio je žvakaće gume i 59,84\% konzumira sokove svakog dana, ali značajno nizak procenat učesnika su aktivni pušači $(17,67 \%)$, nekadašnji pušači $(11,24 \%)$ i korisnici droge $(13,65 \%)$. Procenat studenata koji gricka nokte iznosio je $41,31 \%$.

Ova studija može ukazati na interakcije između oralne higijene i navika u vezi sa tim. Potrebno je dalje istraživanje kako bi se razvile dobre oralne higijenske veštine za postizanje i održavanje oralne i zubne zdravstvene zaštite.

Acta Medica Medianae 2017;56(4):114-119.

Ključne reči: oralno-higijenske navike, oralno zdravlje, studenti 